\title{
Whither the Chukchi Slope Current?
}

\author{
Samuel Boury, ${ }^{\mathrm{a}}$ Robert S. Pickart,${ }^{\mathrm{b}}$ PhilipPe Odier, ${ }^{\mathrm{a}}$ Peigen Lin, ${ }^{\mathrm{b}}$ Min Li, ${ }^{\mathrm{c}}$ \\ Elizabeth C. Fine, ${ }^{\mathrm{d}}$ Harper L. Simmons, ${ }^{\mathrm{e}}$ Jennifer A. MacKinnon, ${ }^{\mathrm{d}}$ And Thomas Peacock ${ }^{\mathrm{f}}$ \\ ${ }^{a}$ Univ. Lyon, ENS de Lyon, Univ. Claude Bernard, CNRS, Laboratoire de Physique, Lyon, France \\ ${ }^{\mathrm{b}}$ Woods Hole Oceanographic Institution, Woods Hole, Massachusetts \\ ${ }^{c}$ Guangdong Province Key Laboratory for Coastal Ocean Variation and Disaster Prediction, Guangdong Ocean University, \\ Zhanjiang, China \\ ${ }^{\mathrm{d}}$ Scripps Institution of Oceanography, University of California, San Diego, La Jolla, California \\ ${ }^{\mathrm{e}}$ School of Fisheries and Ocean Sciences, University of Alaska Fairbanks, Fairbanks, Alaska \\ ${ }^{\mathrm{f}}$ Department of Mechanical Engineering, Massachusetts Institute of Technology, Cambridge, Massachusetts
}

(Manuscript received 11 November 2019, in final form 27 March 2020)

\begin{abstract}
Recent measurements and modeling indicate that roughly half of the Pacific-origin water exiting the Chukchi Sea shelf through Barrow Canyon forms a westward-flowing current known as the Chukchi Slope Current (CSC), yet the trajectory and fate of this current is presently unknown. In this study, through the combined use of shipboard velocity data and information from five profiling floats deployed as quasiLagrangian particles, we delve further into the trajectory and the fate of the CSC. During the period of observation, from early September to early October 2018, the CSC progressed far to the north into the Chukchi Borderland. The northward excursion is believed to result from the current negotiating Hanna Canyon on the Chukchi slope, consistent with potential vorticity dynamics. The volume transport of the CSC, calculated using a set of shipboard transects, decreased from approximately $2 \mathrm{~Sv}\left(1 \mathrm{~Sv} \equiv 10^{6} \mathrm{~m}^{3} \mathrm{~s}^{-1}\right)$ to near zero over a period of 4 days. This variation can be explained by a concomitant change in the wind stress curl over the Chukchi shelf from positive to negative. After turning northward, the CSC was disrupted and four of the five floats veered offshore, with one of the floats permanently leaving the current. It is hypothesized that the observed disruption was due to an anticyclonic eddy interacting with the CSC, which has been observed previously. These results demonstrate that, at times, the CSC can get entrained into the Beaufort Gyre.
\end{abstract}

\section{Introduction}

Pacific waters enter the western Arctic Ocean through Bering Strait, supplying nutrients, carbon, heat, and freshwater (Lowry et al. 2015) to the Chukchi Sea and ultimately the interior basin. It is now well established that these waters progress through the Chukchi Sea via three main pathways: a western branch flowing into Herald Canyon, a central branch flowing between Herald and Hanna Shoals, and an eastern branch situated adjacent to the Alaskan coast that feeds Barrow Canyon (Weingartner et al. 2005) (Fig. 1). Some portion of the western and central branches are believed to turn east before entering the Canada Basin, augmenting the flow through and out of Barrow Canyon (Gong and Pickart 2015; Pickart et al. 2016).

Corresponding author: Samuel Boury, samuel.boury@ens-lyon.fr
Different seasonal water masses are found in the Chukchi Sea. In winter and early spring much of the shelf contains newly ventilated winter water (WW) near the freezing point (Pickart et al. 2016; Pacini et al. 2019). This water is subsequently warmed via mixing and solar heating, becoming what is known as remnant winter water (RWW) (Gong and Pickart 2015). Later in the summer season two types of water enter the Chukchi Sea from the south. The warmest of these is Alaskan Coastal Water (ACW), which originates from runoff into the Gulf of Alaska and flows northward in the Alaskan Coastal Current (ACC) (Paquette and Bourke 1974). The second summer water mass is Bering Summer Water (BSW), which is a mixture of Anadyr Water and central Bering Shelf Water (Coachman et al. 1975). Finally, a combination of sea ice meltwater and river runoff (referred to as MWR) provides freshwater to the surface layer. How and where these water masses exit the 


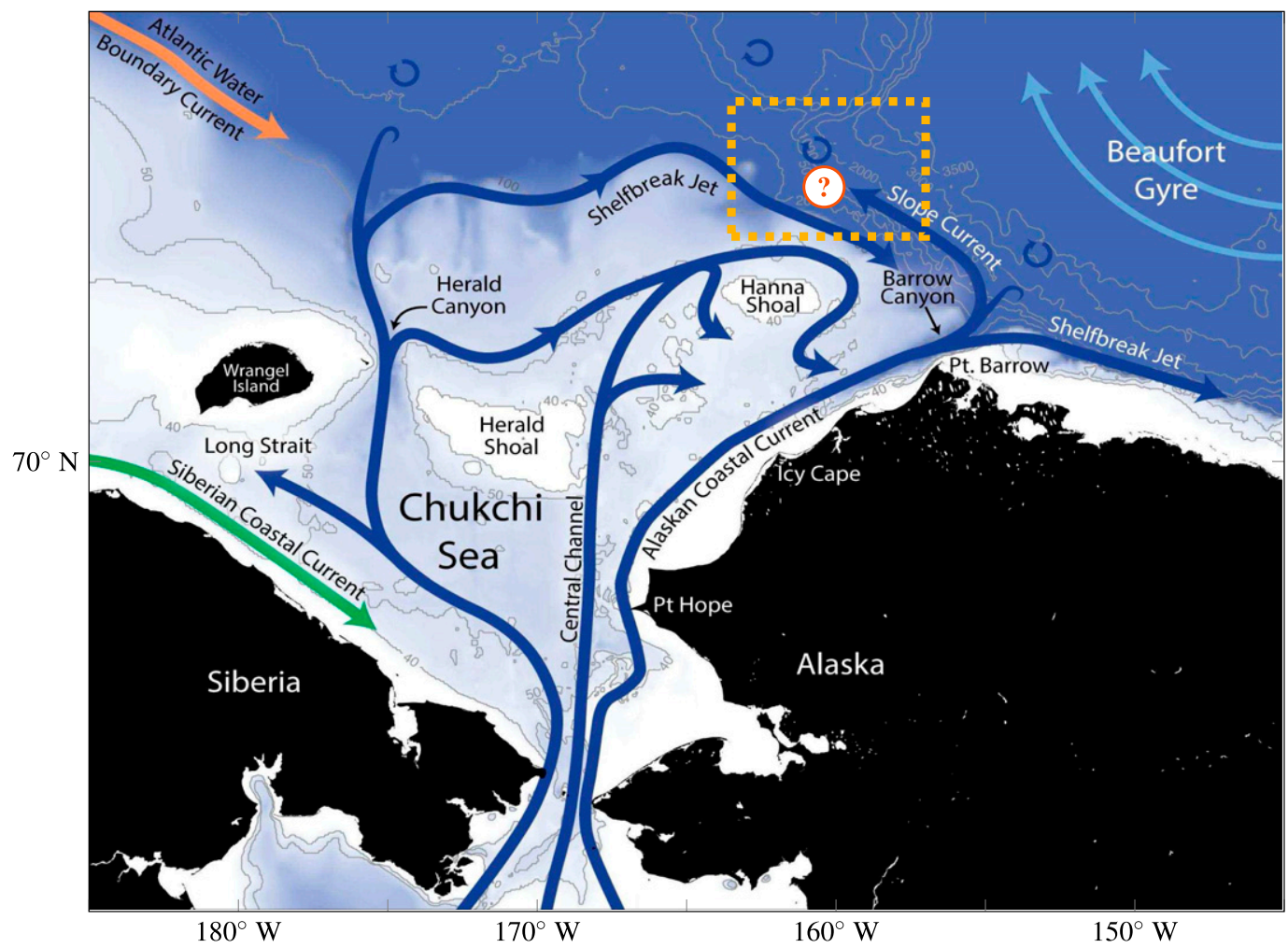

FIG. 1. Schematic representation of the general circulation in the Chukchi Sea, adapted from Corlett and Pickart (2017). The ultimate destination of the Slope Current is currently unknown, hence the reason for the question mark. The dashed yellow rectangle shows the location of the ADCP measurements shown in Fig. 2.

Chukchi Sea into the Canada Basin is a subject of ongoing study.

Recent attention has been placed on Barrow Canyon and the fate of the water draining through the canyon. Originally it was thought that most of the water turned eastward, forming the Beaufort shelfbreak jet (Pickart 2004). Mooring data from the shelfbreak jet, however, revealed that the volume flux of the jet is substantially less than the transport through Bering Strait (Nikolopoulos et al. 2009). This discrepancy has been reconciled with the recent discovery of the Chukchi Slope Current (CSC). Using shipboard acoustic Doppler current profiler (ADCP) data from 46 transects collected between 2002 and 2014, Corlett and Pickart (2017) provided evidence of a westward-flowing current over the continental slope of the Chukchi Sea transporting $0.50 \mathrm{~Sv}\left(1 \mathrm{~Sv} \equiv 10^{6} \mathrm{~m}^{3} \mathrm{~s}^{-1}\right)$ of Pacific Water. They demonstrated that the CSC closes the mass budget of the Chukchi shelf inflows and outflows. The hydrographic data revealed that, during the summer and early fall, the CSC advects mainly RWW. However, the relative presence of the different Pacific water masses in the current varies from month to month.

The year-round presence of the CSC was recently confirmed by Li et al. (2019) using data from a mooring array deployed $100 \mathrm{~km}$ to the west of Barrow Canyon from 2013 to 2014. Li et al. (2019) calculated a mean Pacific Water transport of $0.57 \mathrm{~Sv}$, in line with the shipboard estimate from Corlett and Pickart (2017). The seasonality and mesoscale spatial and temporal variability of the CSC was also investigated by $\mathrm{Li}$ et al. (2019). They determined that the current is surface intensified in summer and fall with a larger transport, and middepth intensified in winter and spring, as it moves shoreward, with a smaller transport. On shorter time scales the CSC was found to vary in concert with the Chukchi shelfbreak jet, which is located farther inshore and typically flows eastward. The dominant mode of variability was associated with two "extreme states," one in which the CSC is strong and the shelfbreak jet is reversed (flowing to the west), and the other in which the CSC is weak and the shelfbreak jet flows strongly to the east. Using reanalysis wind data and a simple model, Li et al. (2019) demonstrated that these two states are dictated by the wind stress curl over the Chukchi shelf. In the first state, the wind stress curl over the shelf is positive, which leads to a drop in sea surface height on the shelf; this in turn drives westward flow at the edge of the shelf via geostrophic set up. In the second extreme 
TABLE 1. ALTO float deployment information.

\begin{tabular}{cccccc}
\hline \hline Name & Float ID & Latitude $(\mathrm{N})$ & Longitude $(\mathrm{W})$ & Release time & Ocean depth \\
\hline $\mathrm{A}$ & 11012 & $73^{\circ} 12.971^{\prime}$ & $159^{\circ} 44.281^{\prime}$ & 0136 UTC 6 Sep & $1001 \mathrm{~m}$ \\
$\mathrm{~B}$ & 11014 & $73^{\circ} 11.710^{\prime}$ & $159^{\circ} 48.981^{\prime}$ & 0155 UTC 6 Sep & $482 \mathrm{~m}$ \\
$\mathrm{C}$ & 11015 & $73^{\circ} 10.365^{\prime}$ & $159^{\circ} 53.431^{\prime}$ & 0214 UTC 6 Sep & $386 \mathrm{~m}$ \\
$\mathrm{D}$ & 11016 & $73^{\circ} 09.091^{\prime}$ & $159^{\circ} 57.780^{\prime}$ & 0232 UTC 6 Sep & $338 \mathrm{~m}$ \\
$\mathrm{E}$ & 11018 & $73^{\circ} 07.808^{\prime}$ & $160^{\circ} 02.455^{\prime}$ & 0241 UTC 6 Sep & $293 \mathrm{~m}$ \\
\hline
\end{tabular}

state the curl is negative, and the associated increase in sea surface height on the shelf intensifies the shelfbreak jet and weakens the CSC.

While both Corlett and Pickart (2017) and Li et al. (2019) argued that the CSC emanates from Barrow Canyon, they did not have direct evidence of this. However, surface drifter data suggest that this is the case (Stabeno et al. 2018). In addition, results from two recent model studies support the notion that the current forms from the outflow from the canyon. First, Spall et al. (2018) demonstrated that the majority of the volume flux leaving the Chukchi shelf occurs in Barrow Canyon via nonlinear advection. This outflow subsequently divides, with a portion forming the eastwardflowing Beaufort shelfbreak jet and the majority of it forming the westward-flowing CSC. The model CSC was found to transport around $0.5 \mathrm{~Sv}$, consistent with in situ measurements (Corlett and Pickart 2017; Li et al. 2019). This result is in contrast to the off-shelf subduction mechanism proposed by Timmermans et al. (2017). Second, the model results of Watanabe et al. (2017) also showed evidence of the CSC, which was responsible for a plume of Pacific Water extending along the slope toward the Northwind Ridge.

The observational study of Corlett and Pickart (2017) revealed a second region of westward flow at the seaward edge of their mean transect across the Chukchi slope, which they interpreted to be the southern edge of the Beaufort Gyre. The model study of Spall et al. (2018) showed a similar distinction between the CSC and the gyre. This interpretation was supported by different model runs that isolated the two circulation features. At this point, however, it is unclear what the fate of the CSC is and how the water masses within the current are modified upon leaving the shelf. Does the CSC remain a distinct feature on the continental slope? The surface drifter results of Stabeno et al. (2018) suggest that this may be the case. Does the CSC ultimately get entrained in the Beaufort Gyre? What is the fate of the heat carried by the current? These questions motivate further investigation of the current and its downstream evolution.

In this paper we present the results of a study of the CSC using five profiling floats configured to be quasiLagrangian particles following the current. This is the first observational effort to address the fate of the Pacific Water as it advects westward away from Barrow Canyon. Section 2 describes the data sources and methods used, namely, the shipboard velocity and hydrographic data in addition to the array of profiling floats. In section 3 we first describe the basic state of the CSC as it was observed in September 2018, mapping the current and its properties along the western part of the Chukchi shelfbreak to the Northwind Ridge. This is followed by an analysis of the profiling float data showing the course of the current, including two instances in which the CSC was abruptly altered. Our conclusions are drawn in section 4.

\section{Data sources and methods}

The in situ data presented in this study were collected during the Stratified Ocean Dynamics of the Arctic (SODA) cruise on the R/V Sikuliaq from 1 to 30 September 2018 (SKQ201819S). Additional data from the HLY1801 cruise on the USCGC Healy from 4 to 24 August 2018 are included.

\section{a. Shipboard ADCP}

Shipboard ADCP measurements of the current were obtained for nine transects across the Chukchi shelfbreak/slope during SKQ201819S. The data were acquired using the University of Hawaii Data Acquisition System (UHDAS) and processed using the Common Ocean Data Access System (CODAS). We use the data from the $300-\mathrm{kHz}$ instrument, sampling at $1.1 \mathrm{~Hz}$, which had reliable coverage in the upper $80 \mathrm{~m}$ of the water column. The accuracy is estimated to be $\pm 2 \mathrm{~cm} \mathrm{~s}^{-1}$. An additional ADCP transect across the shelfbreak/slope was obtained from HLY1801, using a $150-\mathrm{kHz}$ instrument. The reader is referred to Lin et al. (2019) for information regarding the collection and processing of those data. Bathymetry along the transects was obtained by the echosounders on the two vessels.

\section{b. ALTO floats}

Five ALTO floats from MRV systems were deployed on 6 September while occupying a transect across the CSC. The deployment details are presented in Table 1. 


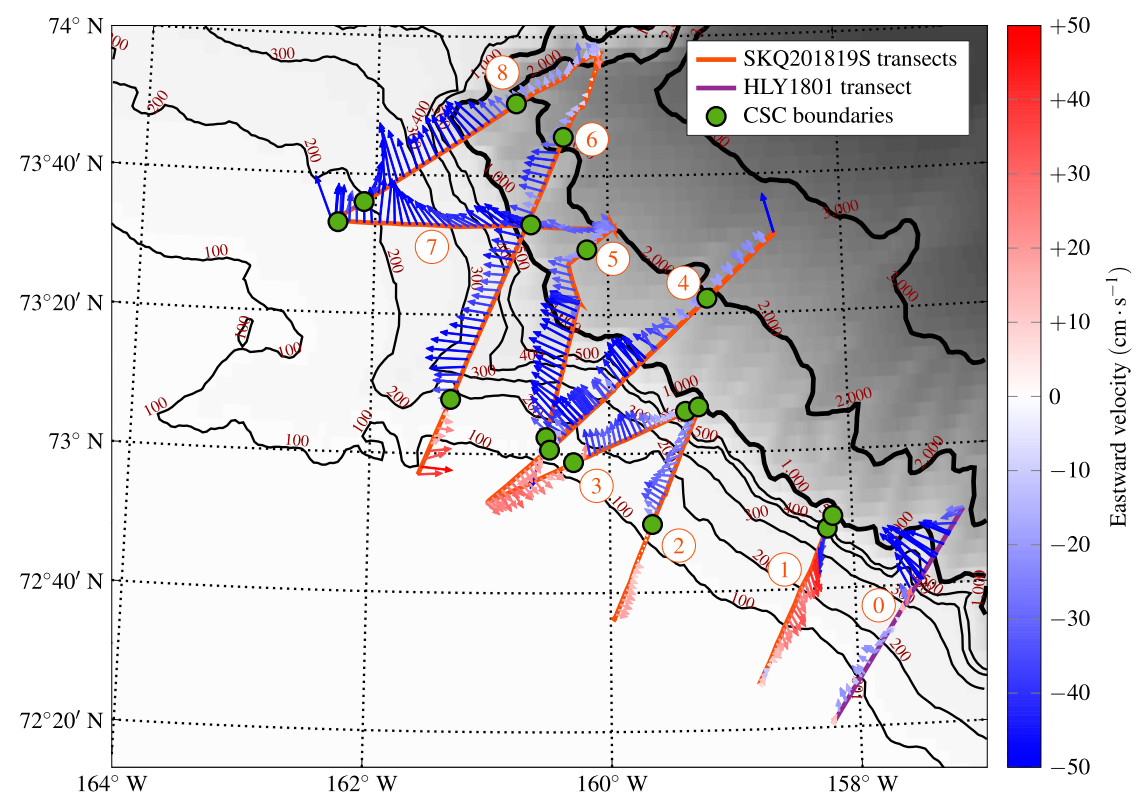

FIG. 2. Overview of the southwest portion of the Canada Basin. The orange line segments show the shipboard transects. The arrows represent the depth-averaged flow over the upper $80 \mathrm{~m}$, colored from blue to red depending on whether the flow is heading west (blue, associated with the CSC) or east (red, associated with the shelfbreak jet). The different currents in the region are the shelfbreak jet, the Chukchi Slope Current, and the southern edge of the Beaufort Gyre. Transects from upstream to downstream (in the sense of the CSC) are numbered from 0 to 8. The green circles indicate the estimated limits of the CSC for the different transects (see text).

All of the floats were equipped with Sea-Bird Electronics (SBE 41) conductivity-temperature-depth (CTD) sensors, providing hydrographic profiles throughout their rise and fall. ALTO sensor accuracies are $\pm 0.002^{\circ} \mathrm{C}$ for temperature, $\pm 0.01 \mathrm{psu}$ for corrected salinity, and $\pm 2.4 \mathrm{dbar}$ for pressure. Their records were transmitted with UTC time and position via Iridium satellite. The floats were configured to profile down and up to depths of $80-100 \mathrm{~m}$ in order to stay in the core of the surfaceintensified CSC. Each profile took roughly $2 \mathrm{~h}$ to complete, of which $1 \mathrm{~h}$ was spent at the surface for operational reasons, $25 \mathrm{~min}$ was spent on descent and ascent, and approximately $10 \mathrm{~min}$ was spent at the deepest descent depth. It took a few profiles to achieve the target depth of around $80 \mathrm{~m}$, with the initial dives being as deep as $250 \mathrm{~m}$, then closing in on the desired maximum depth over a few (3-5) profiles. The deployment of the floats was conducted in two steps. First, a transect across the current was carried out by the ship starting from the $100 \mathrm{~m}$ isobath and extending to the $2500-\mathrm{m}$ isobath. This provided information on the lateral and vertical structure of the CSC. Based on this information, the floats were then deployed across the current on a return transect a few hours later (transect 4 in Fig. 2).

The ALTO floats were thus used in a novel way, as quasi-Lagrangian particles in the current. Since the current is surface-intensified at this time of year, it is expected that they would reasonably follow the current in spite of their up and down motion. As a result, local temperature and salinity measurements were transmitted as a function of depth at different positions of the current, and the different profiles across the current are expected to be correlated.

\section{c. Fast $C T D$}

The Scripps Institution of Oceanography Fast CTD (FCTD; see, e.g., Pinkel et al. 2012) was deployed to collect high-resolution conductivity and temperature measurements along several transects. The FCTD profiles at $5 \mathrm{~m} \mathrm{~s}^{-1}$ up and down from the end of a 32-ft-long boom deployed from the starboard quarter. A Sea-Bird Electronics (SBE 39) CTD sensor on a streamlined drop body samples at $16 \mathrm{~Hz}$ with an accuracy of $\pm 0.002^{\circ} \mathrm{C}$ for temperature, $\pm 0.0003 \mathrm{~S} \mathrm{~m}^{-1}$ for conductivity, and $\pm 1 \mathrm{~m}$ for depth. At a typical steaming speed of $3-4 \mathrm{kt}$ $\left(1 \mathrm{kt} \approx 0.51 \mathrm{~m} \mathrm{~s}^{-1}\right)$, profiles down to $300-\mathrm{m}$ depth were spaced $400 \mathrm{~m}$ along the ship motion direction.

\section{d. Ancillary data}

To assess the impact of wind forcing on the CSC during our study period, we use the European Center for Medium-Range Weather Forecasts (ECMWF) 
TABLE 2. Records of the different transects. Transect $4^{\star}$ corresponds to the ALTO deployments.

\begin{tabular}{|c|c|c|c|c|}
\hline Transect & Cruise & FCTD & Time & End points \\
\hline \multirow[t]{2}{*}{0} & HLY1801 & No & 0575 UTC 19 Aug & $\left(72.84^{\circ} \mathrm{N}, 157.1^{\circ} \mathrm{W}\right)$ \\
\hline & & & to 1412 UTC 19 Aug & $\left(72.34^{\circ} \mathrm{N}, 158.2^{\circ} \mathrm{W}\right)$ \\
\hline \multirow[t]{2}{*}{1} & SKQ201819S & Yes & 1530 UTC 7 Sep & $\left(72.86^{\circ} \mathrm{N}, 158.1^{\circ} \mathrm{W}\right)$ \\
\hline & & & to $0000 \mathrm{UTC} 8 \mathrm{Sep}$ & $\left(72.46^{\circ} \mathrm{N}, 158.8^{\circ} \mathrm{W}\right)$ \\
\hline \multirow[t]{2}{*}{2} & SKQ201819S & Yes & 2250 UTC 6 Sep & $\left(73.12^{\circ} \mathrm{N}, 169.2^{\circ} \mathrm{W}\right)$ \\
\hline & & & to 0824 UTC 7 Sep & $\left(72.61^{\circ} \mathrm{N}, 159.9^{\circ} \mathrm{W}\right)$ \\
\hline \multirow[t]{2}{*}{3} & SKQ201819S & Yes & 1230 UTC 6 Sep & $\left(72.89^{\circ} \mathrm{N}, 161.0^{\circ} \mathrm{W}\right)$ \\
\hline & & & to 2233 UTC 6 Sep & $\left(73.12^{\circ} \mathrm{N}, 159.2^{\circ} \mathrm{W}\right)$ \\
\hline \multirow[t]{2}{*}{4} & SKQ201819S & No & 1716 UTC 5 Sep & $\left(72.99^{\circ} \mathrm{N}, 160.6^{\circ} \mathrm{W}\right)$ \\
\hline & & & to 1955 UTC 5 Sep & $\left(73.52^{\circ} \mathrm{N}, 158.6^{\circ} \mathrm{W}\right)$ \\
\hline \multirow[t]{2}{*}{$4^{\star}$} & SKQ201819S & No & 2219 UTC 5 Sep & $\left(73.52^{\circ} \mathrm{N}, 158.6^{\circ} \mathrm{W}\right)$ \\
\hline & & & to 1230 UTC 4 Sep & $\left(72.89^{\circ} \mathrm{N}, 161.0^{\circ} \mathrm{W}\right)$ \\
\hline \multirow[t]{2}{*}{5} & SKQ201819S & No & 0936 UTC 5 Sep & $\left(73.54^{\circ} \mathrm{N}, 159.9^{\circ} \mathrm{W}\right)$ \\
\hline & & & to 1648 UTC 5 Sep & $\left(72.99^{\circ} \mathrm{N}, 160.6^{\circ} \mathrm{W}\right)$ \\
\hline \multirow[t]{2}{*}{6} & SKQ201819S & No & 0000 UTC 4 Sep & $\left(72.95^{\circ} \mathrm{N}, 161.6^{\circ} \mathrm{W}\right)$ \\
\hline & & & to 1312 UTC 4 Sep & $\left(73.96^{\circ} \mathrm{N}, 160.1^{\circ} \mathrm{W}\right)$ \\
\hline \multirow[t]{2}{*}{7} & SKQ201819S & No & 2316 UTC 4 Sep & $\left(73.55^{\circ} \mathrm{N}, 162.4^{\circ} \mathrm{W}\right)$ \\
\hline & & & to 0936 UTC 5 Sep & $\left(73.54^{\circ} \mathrm{N}, 159.9^{\circ} \mathrm{W}\right)$ \\
\hline \multirow[t]{2}{*}{8} & SKQ201819S & No & 1912 UTC 4 Sep & $\left(73.96^{\circ} \mathrm{N}, 160.1^{\circ} \mathrm{W}\right)$ \\
\hline & & & to 2316 UTC 4 Sep & $\left(73.55^{\circ} \mathrm{N}, 162.4^{\circ} \mathrm{W}\right)$ \\
\hline
\end{tabular}

ERA-Interim reanalysis 10-m wind product (Berrisford et al. 2009; Dee et al. 2011). The horizontal resolution is $0.75^{\circ} \times 0.75^{\circ}$, and the temporal resolution is $6 \mathrm{~h}$. These data were used to compute 6-hourly maps of the wind stress curl.

We also use the daily gridded surface geostrophic velocity data for the domain encompassing the float trajectories, provided by Copernicus Marine and Environment Monitoring Service (CMEMS; http:// marine.copernicus.eu/). This product is gridded from multiple altimeter missions, which are all homogenized to the reference mission Jason-2. The horizontal resolution is $0.25^{\circ}$.

Information is used from two previous field programs that addressed aspects of the CSC. The first is the yearlong mooring array mentioned in the introduction (see Li et al. 2019). This consisted of five moorings deployed from October 2013 to September 2014, spanning the outer shelf to upper slope near $157^{\circ} \mathrm{W}$. This provided a year-long view of both the CSC and the Chukchi Shelfbreak Jet. A description of the array, including the instrumentation, data processing, and accuracy of the measurements, can be found in Li et al. (2019). The second field program was carried out in September 2002 aboard the Healy. It included a shipboard survey of a middepth anticyclone of Pacific WW that was embedded on the seaward side of the CSC. The eddy was first identified using expendable bathythermographs (XBTs), then it was mapped at high-resolution using expendable CTDs. The survey took roughly a day to complete and included shipboard ADCP measurements, thus providing a three-dimensional view of the eddy interacting with the CSC. The reader is referred to Scott et al. (2019) for details.

\section{Results}

\section{a. Vertical transects}

During the two cruises, nine transects were occupied across the continental slope of the Chukchi Sea, providing the opportunity to map the CSC (Fig. 2). Eight of the transects were done on SKQ201819S, which are numbered 1 to 8 progressing downstream, with transect $4^{\star}$ corresponding to a repeat of transect 4 during which the ALTO floats were deployed. Transect 0 was occupied on HLY1801 roughly two weeks before the first SKQ201819S section. Information regarding the transects is presented in Table 2. The chronological order of the SKQ201819S sections is as follows: 6, 8, 7, 5, 4 and $4^{\star}$ (i.e., back and forth), 3, 2, and 1 .

Figure 2 displays the velocity vectors averaged over the top $80 \mathrm{~m}$, where the flow directed away from Barrow Canyon is colored blue, and the flow directed toward the canyon is colored red. The latter condition occurs on the shoreward ends of sections 1, 2, 3, 4, and 6. All of these sections extend onto the outer shelf, indicating that the eastward flow is associated with the Chukchi shelfbreak jet. Farther offshore the flow is consistently directed away from the canyon, associated with the CSC. The vertical sections of cross-track velocity from the shipboard ADCP confirm this interpretation. A typical example is shown in Fig. 3, showing the vertical section of cross-track velocity for transect $4^{\star}$. It reveals the bottom-intensified eastward flow of the shelfbreak jet, 


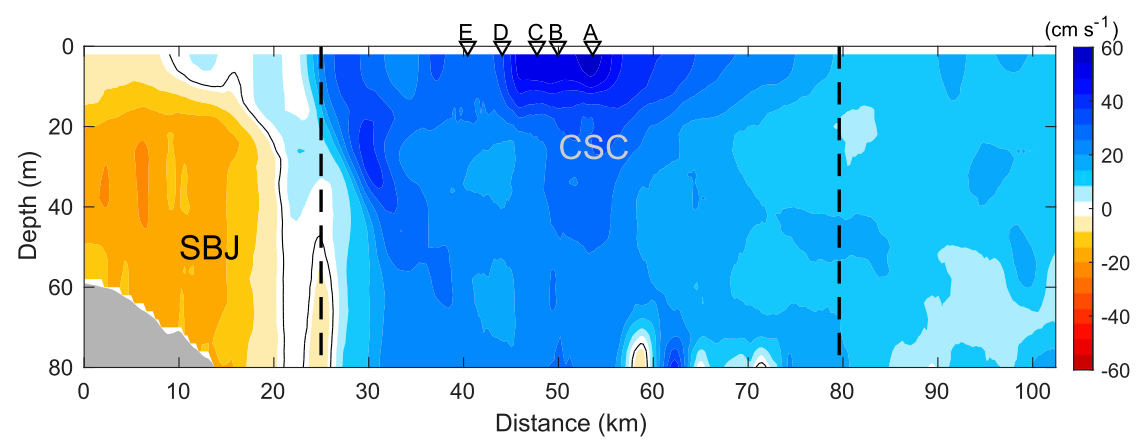

FIG. 3. Vertical section of cross-track velocity for transect $4^{\star}$. Positive velocity is northwestward (away from Barrow Canyon). The dashed lines indicate the lateral bounds of the Chukchi Slope Current, determined using the procedure described in the text. The labels denote the Chukchi Slope Current (CSC) and Chukchi shelfbreak jet (SBJ). The letters on top, from A through E, indicate the float deployment locations.

and, offshore of this, the surface-intensified westward flow of the CSC. This is the cannonical situation for this time of year, as demonstrated by previous shipboard measurements (Corlett and Pickart 2017) and mooring data (Li et al. 2019).

To quantify the transport of the CSC in the SKQ201819S transects, we implemented the following objective approach (the HLY1801 section was not considered since it was nonsynoptic with the rest of the dataset). Using the ADCP data in the top $20 \mathrm{~m}$ (since the CSC is surface intensified in this season), we identified the core of the CSC and took the width of the current to be where the velocity dropped to $20 \%$ of the peak value. We have marked the lateral boundaries of the CSC based on this criterion, in Fig. 2 with green circles, and in Fig. 3 using dashed lines. The westward flow offshore of the CSC is likely the southern edge of the Beaufort Gyre (see Corlett and Pickart 2017; Spall et al. 2018). On two of the nine transects the $20 \%$ condition was not met on the seaward side of the CSC (i.e., the flow remained fairly strong until the edge of the section). In these two instances (sections 2 and 3) the edge of the CSC was taken to be the offshore end of the transect.

The along-slope volume flux of the CSC for the $n$th transect is given by

$$
\Phi^{(n)}=\int_{x_{L}}^{x_{R}} \int_{z=0 \mathrm{~m}}^{z=80 \mathrm{~m}} u_{c, \perp}^{(n)} d x d z
$$

where $u_{c, \perp}^{(n)}$ is the CSC velocity orthogonal to the considered transect, and $x_{L}$ and $x_{R}$ the left and right bounds of the CSC as previously defined. The integration area is therefore delimited horizontally by the bounds marked on Fig. 2 for each transect, and vertically from the surface to $80 \mathrm{~m}$. Each of the ADCP sections was extrapolated to the sea surface using an objective Laplacian-Spline scheme (e.g., Pickart and Smethie 1998). The CSC of course extends deeper than $80 \mathrm{~m}$ (see Corlett and Pickart 2017; Li et al. 2019), but we are limited here by the range of the $300-\mathrm{kHz}$ ADCP. To account for this we used the data from the year-long array of five moorings described in section $2 \mathrm{~d}$, which was located $25 \mathrm{~km}$ to the east of transect 0 . These data indicate that, for the month of September, integrating to $80 \mathrm{~m}$ accounts for $72 \%$ of the CSC transport. As such, we scaled-up our estimates by a factor of $1 / 0.72=1.39$. The resulting CSC transports for the SKQ201819S transects are given in Table 3 and shown in Fig. 4 (top). The measured volume flux systematically decreased from $1.95 \mathrm{~Sv}$ (transect 6) to 0 (transect 1) over the course of the experiment with an average value of $1.03 \pm 0.20 \mathrm{~Sv}$ for the 9 transects. The mean is substantially larger than the year-long mean value reported by $\mathrm{Li}$ et al. (2019) $(0.57 \mathrm{~Sv})$ and the summertime mean value given by Corlett and Pickart (2017) (0.50 Sv). The latter of these two values, however, represents the Pacific Water component of the current, that is, excluding the

TABLE 3. Volume transport for the different transects.

\begin{tabular}{ccc}
\hline \hline Transect & $\begin{array}{c}\text { Volume } \\
\text { transport }(\mathrm{Sv})\end{array}$ & $\begin{array}{c}\text { Laterally integrated surface } \\
\text { geostrophic velocity }\left(\times 10^{4} \mathrm{~m}^{2} \mathrm{~s}^{-1}\right)\end{array}$ \\
\hline 1 & 1.947 & 1.651 \\
2 & 1.683 & 1.152 \\
3 & 1.022 & 0.978 \\
4 & 1.336 & 0.945 \\
$4^{\star}$ & 1.003 & 0.687 \\
5 & 1.259 & 0.833 \\
6 & 0.508 & 0.362 \\
7 & 0.496 & 0.351 \\
8 & 0.009 & 0.027 \\
\hline
\end{tabular}



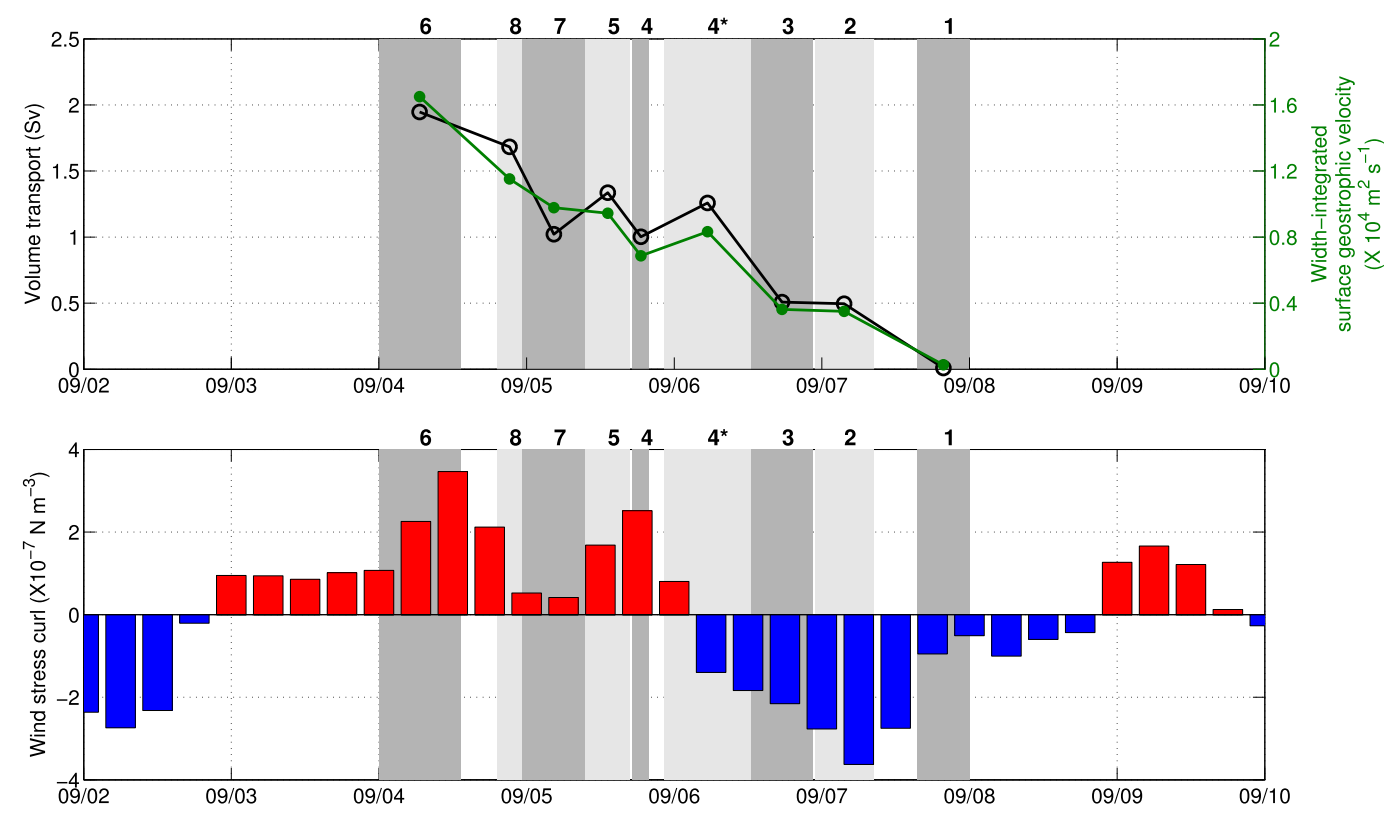

FIG. 4. (top) Volume transport of the CSC using the SKQ201819S shipboard ADCP data (black symbols) and laterally integrated cross-track surface velocity over the width of the CSC using the altimetry product (green symbols). (bottom) Wind stress curl every $6 \mathrm{~h}$ averaged over the northeast Chukchi shelf (see text). The time of occupation of the SKQ201819S transects are shaded gray and numbered along the top.

meltwater and riverine contributions that are mainly present in the upper layer. While we have no way of extracting the Pacific Water contribution, we note that the full transport of the CSC for the month of September 2014 reported by Li et al. (2019) was $0.99 \mathrm{~Sv}$, which is in line with the mean value reported here for the September 2018 survey.

Why is there such a large range of transport values in the SKQ201819S dataset? We argue that this is due to the variable wind forcing during the survey. As noted in the introduction, Li et al. (2019) demonstrated that the strength of the CSC is strongly modulated by the wind stress curl on the Chukchi shelf via geostrophic set up. When the wind stress curl is positive, the corresponding drop in sea surface height (leading to a sea surface gradient across the Chukchi slope) results in a stronger CSC. When the wind stress curl is negative on the shelf the opposite happens and the CSC weakens or reverses. To assess this effect in our dataset, we constructed a time series of average wind stress curl over the same region of the shelf considered by $\mathrm{Li}$ et al. (2019), presented in Fig. 4 (bottom). Our study reveals that there was a prolonged period of positive wind stress curl during the first part of the SKQ201819S survey, followed by a prolonged period of negative wind stress curl during the later part of the survey. The results in Fig. 4 reveal that there is a general consistency between the wind stress curl and the CSC transport in line with the previous results of $\mathrm{Li}$ et al. (2019). That is, the current tends to be strong during periods of positive curl, and weak (or reversed) during periods of negative curl.

This result is corroborated by considering the gridded absolute geostrophic velocity product from altimetry described in section $2 d$. Since the CSC is surfaceintensified at this time of year, the daily satellitederived velocity data contains a signal of the current. As such, for each of the SKQ201819S transects in Fig. 2 we computed the width-integrated surface current normal to the transect between the endpoints of the CSC determined above (green curve in Fig. 4, top). This quantity reveals the same trend as is found for the ADCP-derived transports (black curve in Fig. 4, top), providing compelling support for the role of the wind stress curl in dictating the transport of the CSC during the shipboard survey.

\section{b. Float data}

Figure 5 presents the trajectories of the ALTO floats after they were deployed on 6 September on transect $4^{\star}$ within the CSC (Fig. 2). The initial deployment positions of the floats slightly favored the inshore side of the current, due to the fact that the current had seemingly shifted a bit offshore subsequent to the occupation of transect 4 that was used to determine the launch positions. The deployment transect is indicated as line (i) in Fig. 5. The floats transmitted their first data a few hours after deployment. Their trajectory can be divided into three main phases: an initial very coherent motion, 


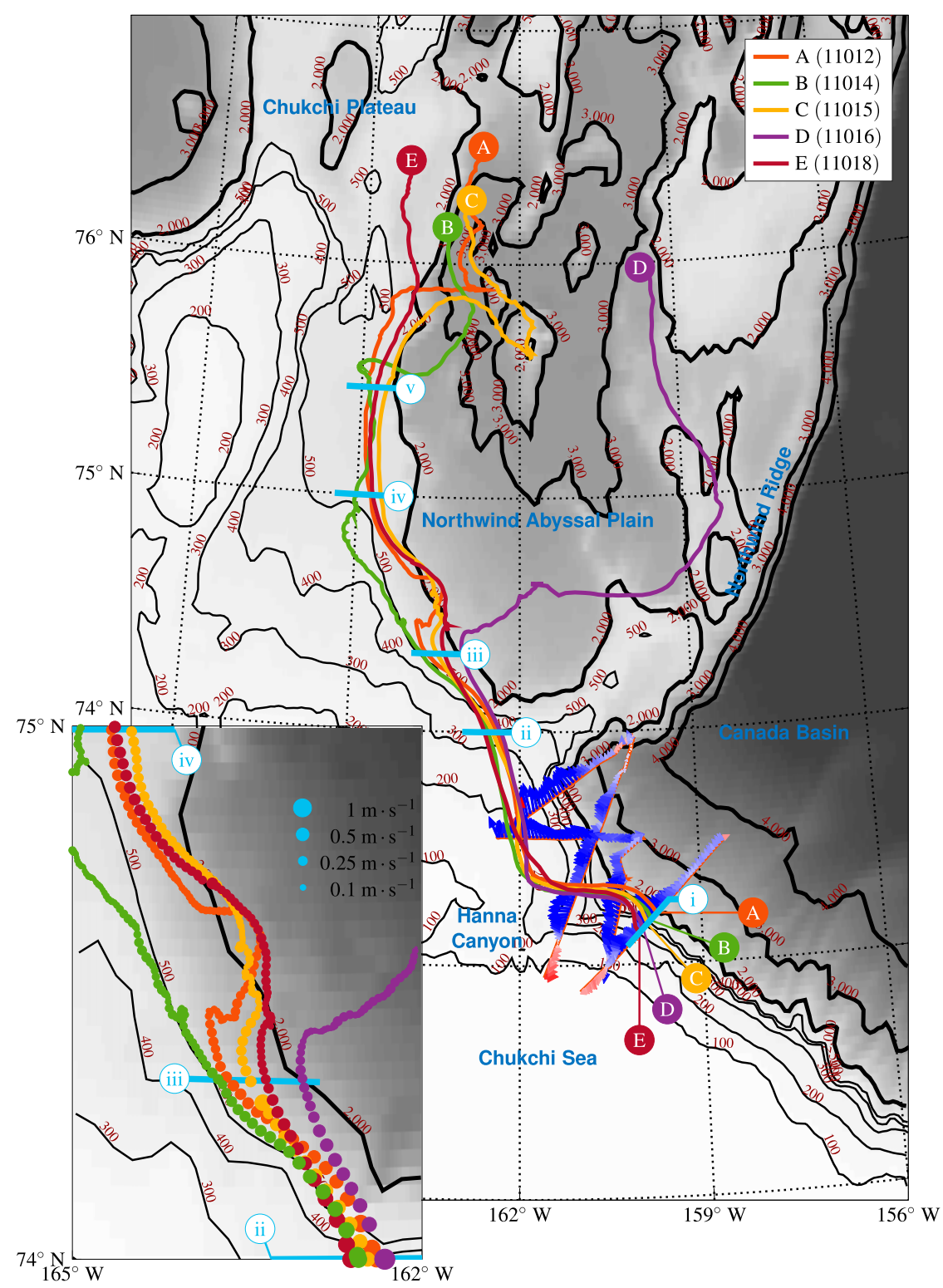

FIG. 5. Trajectories of the five ALTO floats (A-E) superimposed onto the ADCP data and ship transects, indicating the path of the CSC. Sections (i) to (v) are relevant delimitations for the different parts of the float trajectories (see explanation throughout the text). The bottomleft inset shows an enlarged view of the ALTO float trajectories from $74^{\circ}$ to $75^{\circ} \mathrm{N}$. The size of the dots represents the instantaneous velocities of the floats (see the legend).

followed by a disruption, and finally a reappearance of a coherent behavior.

\section{1) BEFORE NORTHWIND RIDGE: INITIAL COHERENT MOTION}

Traveling along the continental slope the floats stayed together in a very coherent fashion. Shortly after deployment, the floats encountered Hanna Canyon near $161^{\circ} \mathrm{W}$. Previous studies have shown that the behavior of a current impinging upon a canyon depends on both the canyon topography and the stratification of the water column (e.g., Klinck 1996; Hickey 1997; Williams et al. 2006). The pertinent parameter is the ratio of the width of the canyon $W$ and the internal Rossby radius of deformation, $R=N H / f$, where $N$ is the buoyancy frequency, $H$ is the water depth, and $f$ is the Coriolis parameter. If this ratio is larger than 2 , then the canyon is considered dynamically wide and the incident current will feel the entire canyon. The width of Hanna Canyon is approximately $100 \mathrm{~km}$. We used the mooring data of 
Li et al. (2019), described in section 2d, to estimate $R$, and found it to be $15-20 \mathrm{~km}$. Hence, Hanna Canyon is dynamically wide. As such, a current encountering the canyon should not simply follow the isobaths around the canyon, but instead get partially diverted into the canyon and progress across isobaths to its downstream flank (Hyun 2004). As discussed in Hyun (2004), when the current encounters the downstream flank, the water column compresses, and, in order to conserve potential vorticity, this induces a negative relative vorticity that causes the current to divert back offshore into deeper water.

This scenario is consistent with the behavior of the CSC in Fig. 5. When the floats first encounter Hanna Canyon they flow into deeper water; that is, they are unable to stay on an isobath, and subsequently cross to the other side of the canyon. As this happens, they progress into shallower water until about $162^{\circ} \mathrm{W}$ (Fig. 5), at which point they turn anticyclonically into deeper water again. This northward excursion appears to be critical to the fate of the CSC; we return to this in the discussion section. It is worth noting as well that the wind stress curl was weak throughout this time period, implying that wind did not play a role in this change in the float trajectories.

On 10 September, roughly four days after their release, the floats passed the Northwind Ridge. Importantly, the floats were shoreward enough that they did not feel the topography of the ridge. That is, the floats continued to flow into deeper water after exiting Hanna Canyon as they flowed past line (ii) in Fig. 5. During the first four days, the fastest floats were $\mathrm{A}$ and $\mathrm{B}$, originally deployed around the 1000- and the 500-m isobaths, respectively. Floats D and E, deployed farther onshore, were the slowest. This difference between the float velocities reveals the structure of the current, stronger offshore around the $1000 \mathrm{~m}$ isobath. As they were advected by the CSC, the floats did not stay in the same cross-shelf configuration and their trajectories crossed each other. This means that, due to the complexities of the CSC structure interacting with the vertical profiling action of the floats, two different floats can pass through the same location at different times. Float E had the least coherent motion, crossing twice over the other trajectories while still remaining in the current. Before leaving the edge of the Canada Basin and crossing line (ii) at the end of the fourth day, the fastest floats had migrated onshore and the slowest offshore. All floats went through line (ii) within a few hours' time difference, which indicates a very coherent CSC during this time window.

Figure 6 (left) presents the temperature profiles of all five floats during their passage along the edge of the Canada Basin. The first profile is taken at the deployment location [line (i) in Fig. 5]. The first $100 \mathrm{~h}$ of each dataset roughly correspond to the trajectory before the floats leave the Canada Basin, that is, prior to passing inshore of the Northwind Ridge $\left[74^{\circ} 06^{\prime} \mathrm{N}\right.$, line (ii) in Fig. 5]. All of the time series have a very coherent structure with cold water at the surface, above a layer of warm water up to $5.5^{\circ} \mathrm{C}$ between 20 and $40 \mathrm{~m}$. After $50 \mathrm{~h}$ the three floats at the outer edge of the current-A, C, and $\mathrm{D}$-show the appearance of cold water, centered around $30 \mathrm{~m}$ (Fig. 6). This happened when the floats reached $162^{\circ} \mathrm{W}$ and started heading north into deeper water instead of going west.

Figure 7 shows a temperature-salinity (TS) plot from the five floats at different locations. In Fig. 7a float profiles are taken at the deployment location [line (i) in Fig. 5]. As noted in the introduction, upon deployment the floats initially profiled as deep as $250 \mathrm{~m}$, and these deeper data are included in Fig. 7a. It reveals that the CSC was advecting MWR at the surface, ACW and BSW below this in the core of the current (20-40-m depth), and RWW deeper than $100 \mathrm{~m}$. Notably, Corlett and Pickart (2017) saw very little ACW in their vertical sections, whereas our results demonstrate that, at times, the CSC can advect a large amount of this warm water westward. This is contrary to the common notion that the ACC mostly feeds the Beaufort shelfbreak jet. It also provides further evidence that the CSC emanates from the outflow from Barrow Canyon (see also Spall et al. 2018; Li et al. 2019). Since the floats profiled to deeper depths at the start of their mission, they measured the presence of Atlantic Water (AW) in Fig. 7a. Both Corlett and Pickart (2017) and Li et al. (2019) found that the CSC advected AW at depth; the reason for this remains unexplored. At line (ii) the CSC was still advecting ACW (Fig. 7b), but one also sees the presence of MWR between $0^{\circ}$ and $-1^{\circ} \mathrm{C}$ in the salinity range $28-30$. This is the same cold water mentioned above measured by the offshore floats A, C, and D starting around $50 \mathrm{~h}$. The water likely originated from the interior of the Canada Basin resulting from local ice melt.

\section{2) After Northwind Ridge: Possible DISRUPTION BY AN EDDY}

After passing the Northwind Ridge, the floats proceeded northwest following the bathymetry until around 13 September when they were nearly arrested on the edge of the Northwind Abyssal Plain, around $74^{\circ} 20^{\prime} \mathrm{N}$ [line (iii) in Fig. 5]. Starting from the east, the floats peeled off one after the other and followed more intricate trajectories; during this time only float $\mathrm{B}$ remained relatively close to following an isobath. This is also the time that the warm water signature disappeared in the float profiles (Fig. 6, dashed line), even showing the 

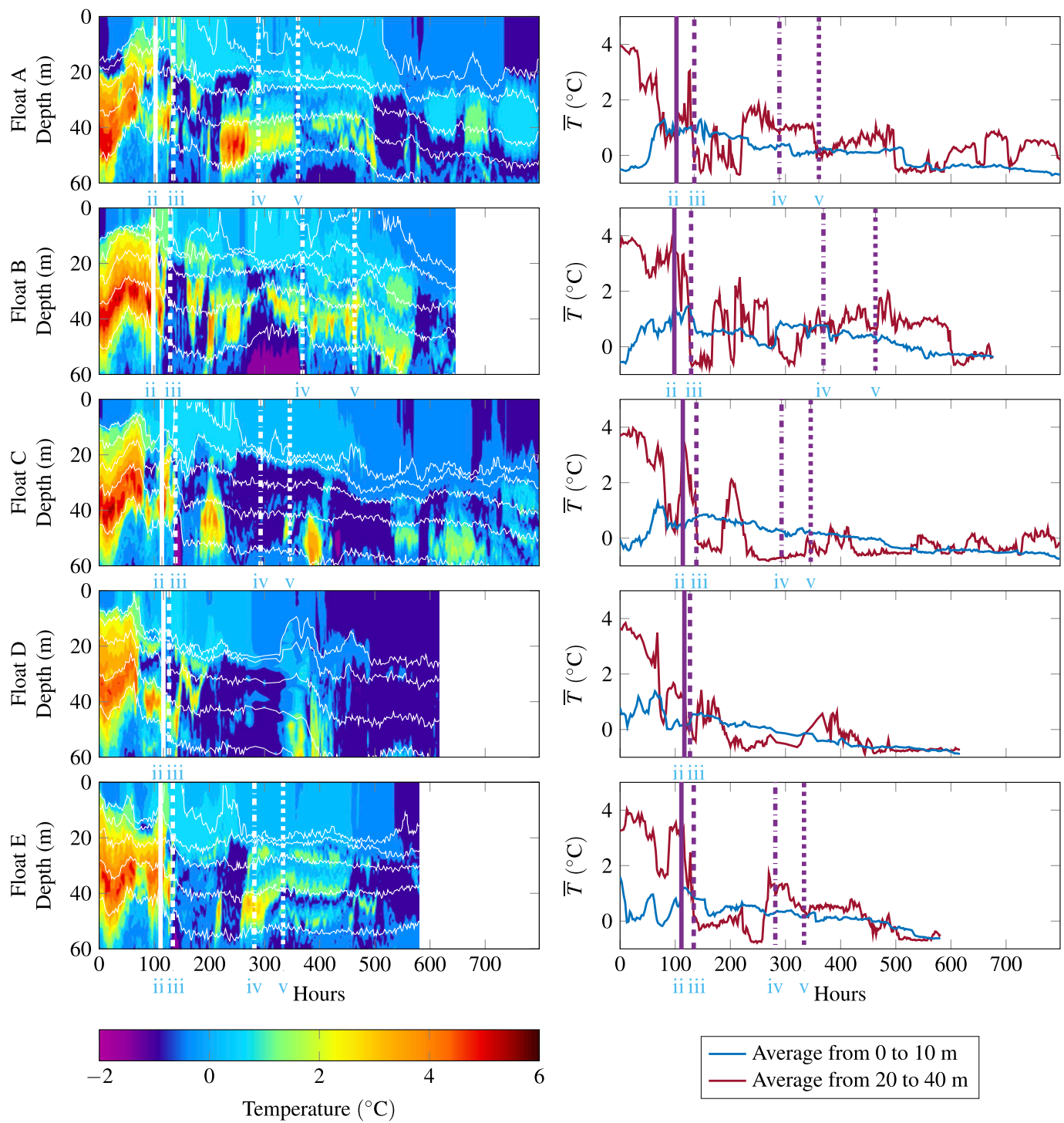

FIG. 6. (left) Depth-time plot of temperature (color) and density (white contours; $\mathrm{kg} \mathrm{m}^{-3}$ ) for each of the five ALTO floats, from top to bottom: A, B, C, D, and E. The selected isopycnals are $21,22,23,24$, and $25 \mathrm{~kg} \mathrm{~m}^{-3}$. (right) Averaged temperature $\bar{T}$ over the top $10 \mathrm{~m}$ (blue) and from 20 to $40 \mathrm{~m}$ (red). The thick vertical white lines in the left column and purple lines in the right column indicate select locations discussed in the text: the first line (solid) shows when the floats are beyond the Northwind Ridge and corresponds to label (ii) in Fig. 5; the second line (dashed) shows when the floats were disrupted, corresponding to label (iii); the third line (dashed-dotted) shows when the floats became well-behaved again, corresponding to label (iv); and the fourth line (dotted) shows when the coherence of the current is lost, marked as line (v).

presence of WW (very cold water with temperature around $-1.8^{\circ} \mathrm{C}$, purple color) below $40 \mathrm{~m}$ for floats $\mathrm{C}$ and E. As shown in Fig. 6, this transition to cold water occurred very abruptly, over a period of 2 to $10 \mathrm{~h}$. This state persisted for approximately four days until floats A, C, and E, veered back into shallower water and started to follow the bathymetry again. By contrast, float $\mathrm{D}$ permanently left the region and proceeded into the Northwind Abyssal Plain. During this period, the float velocities dropped from 1 to $0.1-0.2 \mathrm{~m} \mathrm{~s}^{-1}$, which is nearly an order of magnitude smaller, as shown in the inset of Fig. 5. Such a large decrease in velocity, together with the wandering motion experienced by the floats, show that the current was strongly perturbed.

The region of altered behavior, between $74^{\circ} 20^{\prime}$ and $75^{\circ} \mathrm{N}$, is depicted with TS plots in Fig. 7. In Fig. 7c, measured in this region, one sees a pronounced difference in the TS characteristics of the current. The water 

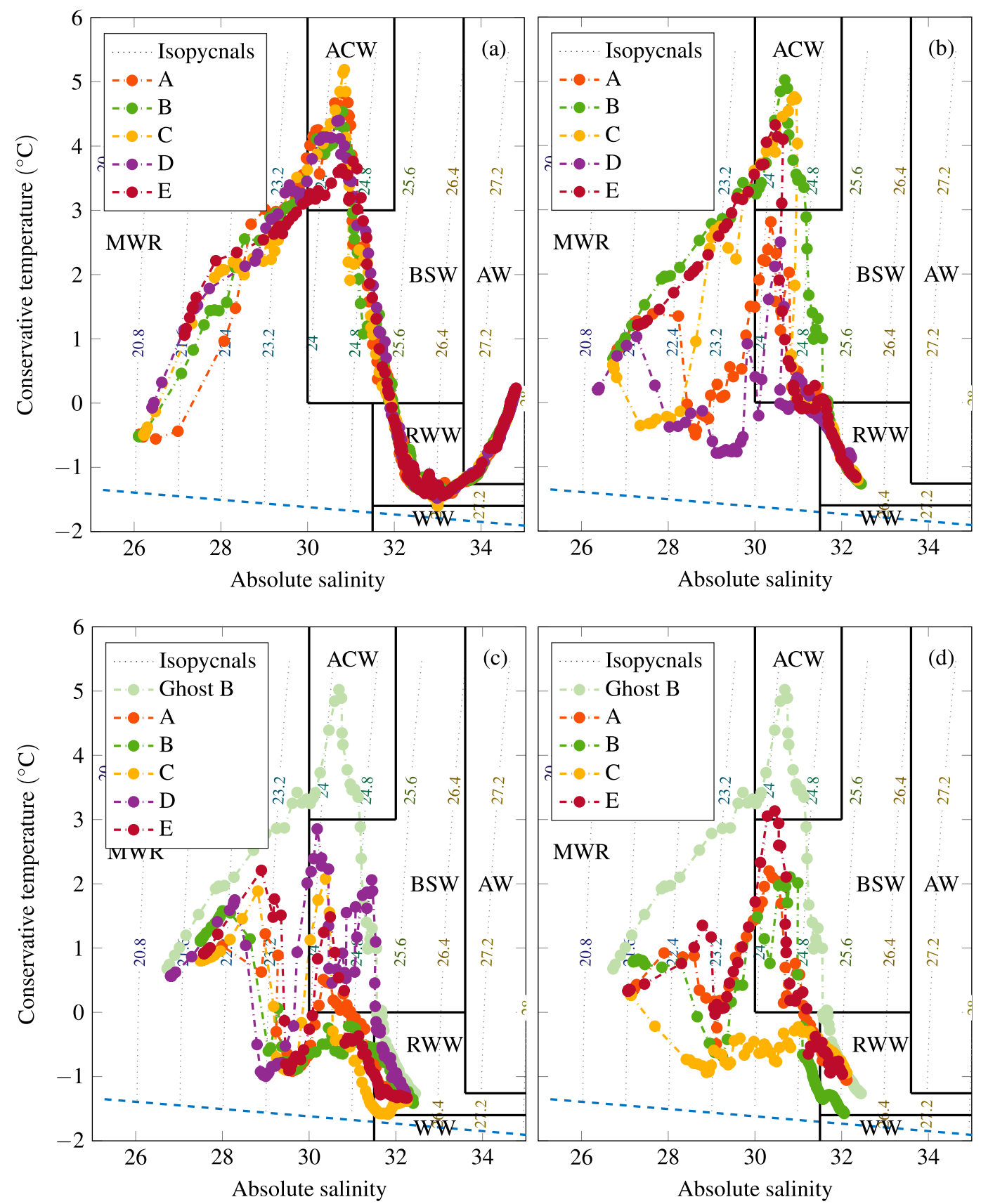

FIG. 7. Temperature-salinity (TS) plots of the five floats (a) at the deployment location on the Chukchi continental slope, from 250-m-deep profiles [location (i) in Fig. 5]; (b) at $74^{\circ} 06^{\prime} \mathrm{N}$, just after leaving the Canada Basin and passing inshore of the Northwind Ridge [location (ii) in Fig. 5], from 80-m depth profiles; (c) at $72^{\circ} 20^{\prime} \mathrm{N}$, where the CSC was disrupted [location (iii) in Fig. 5]; and (d) at $75^{\circ} \mathrm{N}$, where the floats became well-behaved again [location (iv) in Fig. 5]. The thick lines show boundaries between water masses and are taken from Corlett and Pickart (2017). The water mass abbreviations are MWR = sea ice meltwater/river runoff; ACW = Alaskan Coastal Water; BSW = Bering Summer Water; WW = newly ventilated winter water; RWW = remnant winter water; and AW = Atlantic Water. A "ghost profile" in (c) and (d) (float B, before the disruption of the CSC) shows the original TS structure of the CSC. Blue dashed line indicates the freezing line. 
TABLE 4. Densities and temperatures averaged in the vertical between 0 and $80 \mathrm{~m}$ from the profiles in Fig. 6 in the different regions. The last line concerns only floats $\mathrm{A}, \mathrm{B}$, and $\mathrm{E}$.

\begin{tabular}{lcc}
\hline \hline $\begin{array}{c}\text { Region (see Figs. 5 } \\
\text { and 6) }\end{array}$ & $\begin{array}{c}\text { Mean density } \rho \\
\left(\times 10^{3} \mathrm{~kg} \mathrm{~m}^{-3}\right)\end{array}$ & $\begin{array}{c}\text { Mean temperature } \\
T\left({ }^{\circ} \mathrm{C}\right)\end{array}$ \\
\hline $\begin{array}{l}\text { From (i) to (iii) (in the } \\
\text { CSC) }\end{array}$ & 1.0240 & 1.251 \\
$\begin{array}{l}\text { From (iii) to (iv) (eddy } \\
\text { disruption) }\end{array}$ & 1.0235 & 0.162 \\
$\begin{array}{l}\text { From (iv) to (v) (back } \\
\text { in the CSC) }\end{array}$ & 1.0236 & 0.346 \\
\hline
\end{tabular}

composition measured by the floats is now mainly MWR with RWW and some BSW, indicative of strong mixing and influx of cold water into the CSC. A standard feature of Fig. 7c is the absence of the relatively warm ACW peak, these waters having undergone substantial change in properties due to mixing processes, as can be seen in comparison to the ghost float B taken from Fig. 7b. When the floats enter the main part of the current again, this hydrographic structure is still present, although some of the cold, fresh MWR measured upstream reappears (cf. Figs. 7b-d). Vertically averaged temperature signals in Fig. 6 (right) show a pronounced cold signature at the beginning of the perturbed period, with a drop of about $3^{\circ} \mathrm{C}$ in the core of the CSC (from 20 to $40 \mathrm{~m}$ depth, in red). Table 4 presents the densities and temperatures averaged in the vertical from 20- to 40-m depth for the 5 floats from deployment to line (iii), and from line (iii) to line (iv), and for floats A, B, and E from line (iv) to (v), as their profiles show clear signature of the CSC. These three regions-corresponding to the well-established CSC, the period of disruption, and the re-established CSC, respectively-have no significant variation in the mean density, but there is a drop in the mean temperature, from $1.25^{\circ}$ to $0.16^{\circ} \mathrm{C}$, during the perturbed state. When the current reestablishes, the temperature slightly rises from $0.16^{\circ}$ to $0.35^{\circ} \mathrm{C}$. This variation supports the idea that a cold water mass of about the same density influenced the CSC between locations (iii) and (iv). Furthermore, the TS plots in Fig. 7 indicate that the upper layer of the stratification remained unchanged, which is confirmed by the nearly constant average temperature in the top $10 \mathrm{~m}$ (in blue in Fig. 6, right). As a result, the water column sees a supply of cold water from the surroundings, pointing toward a horizontal exchange process rather than vertical mixing for which the vertically averaged temperature would have remain unchanged.

What was the reason for this sudden offshore excursion of the floats and change in hydrographic character? Examination of the wind field during this time indicates that the wind stress curl over the Chukchi shelf was positive. Such forcing would tend to cause the CSC to proceed farther shoreward; hence this cannot explain the offshore excursion. We postulate that an anticyclonic eddy impinged upon the CSC from offshore, perturbing the CSC and mixing the water within the current with surrounding water masses. We note that middepth-intensified anticyclonic eddies are very common in this region (Manley and Hunkins 1985; Plueddemann et al. 1998; Pickart et al. 2005; Mathis et al. 2007; Zhao et al. 2016; Fine et al. 2018). Two examples of interactions of these features with the offshore side of the CSC are shown in Fig. 8. Figures $8 \mathrm{a}$ and $8 \mathrm{~b}$ show along-slope velocity and temperature measurements made in August 2004 (Scott et al. 2019) in the area near transect 8 in our study (see section $2 \mathrm{~d}$ for a description of the data). The presence of a cold core eddy, with a core temperature near $-1.8^{\circ} \mathrm{C}$, interacting with the CSC is clearly seen. Anomalously cold water in such a feature mixing with the CSC could help explain the sudden drop in temperature recorded by the floats near line (iii) (Fig. 6). Figures $8 \mathrm{c}$ and $8 \mathrm{~d}$ show alongslope velocity and temperature from a shipboard CTD section occupied in August 2017, roughly corresponding to transect 5 in the present survey. In this section, a warmcore anticyclone is centered near $80-\mathrm{m}$ water depth. In both cases, the familiar widening of the isopycnals is associated with the azimuthal flow of the eddy, and in both instances the onshore side of the eddy is essentially merged with the offshore side of the CSC. One can envision a float getting entrained and mixed into the eddy, and subsequently getting deflected offshore. Such a scenario is consistent with the fact that, after section (iii), the floats peeled off in sequence-starting from the east: D, E, C, A, $\mathrm{B}$ - and the offshore-most ALTO float underwent the largest excursion, while the onshore-most float remained unperturbed. We note that cold core anticyclones are far more common than warm core anticyclones (Zhao et al. 2014), so it is more likely for the CSC to be impacted by a cold core feature in the manner seen in our data.

\section{3) FARTHER NORTH: RESURRECTION OF THE CSC}

After wandering for four days, three of the floats-A, $\mathrm{C}$, and $\mathrm{E}$ - came back into the restored CSC, joined five days later by a fourth one, B, while the outer-most float, $\mathrm{D}$, was permanently expelled from the current. The reconnection of the four floats implies that the CSC was reestablished for several days beyond $75^{\circ} \mathrm{N}$ [line (iv) in Fig. 5]. These four floats headed north, generally following the bathymetry at $165^{\circ} \mathrm{W}$, but slower than before the disruption of the CSC due to the presumed interaction with an eddy. Furthermore, the warm temperature signal for the returning floats was not as strong as before the interruption. As shown in Fig. 6, the warm water signature went up to $3^{\circ}$ instead of $5^{\circ} \mathrm{C}$. In addition, 

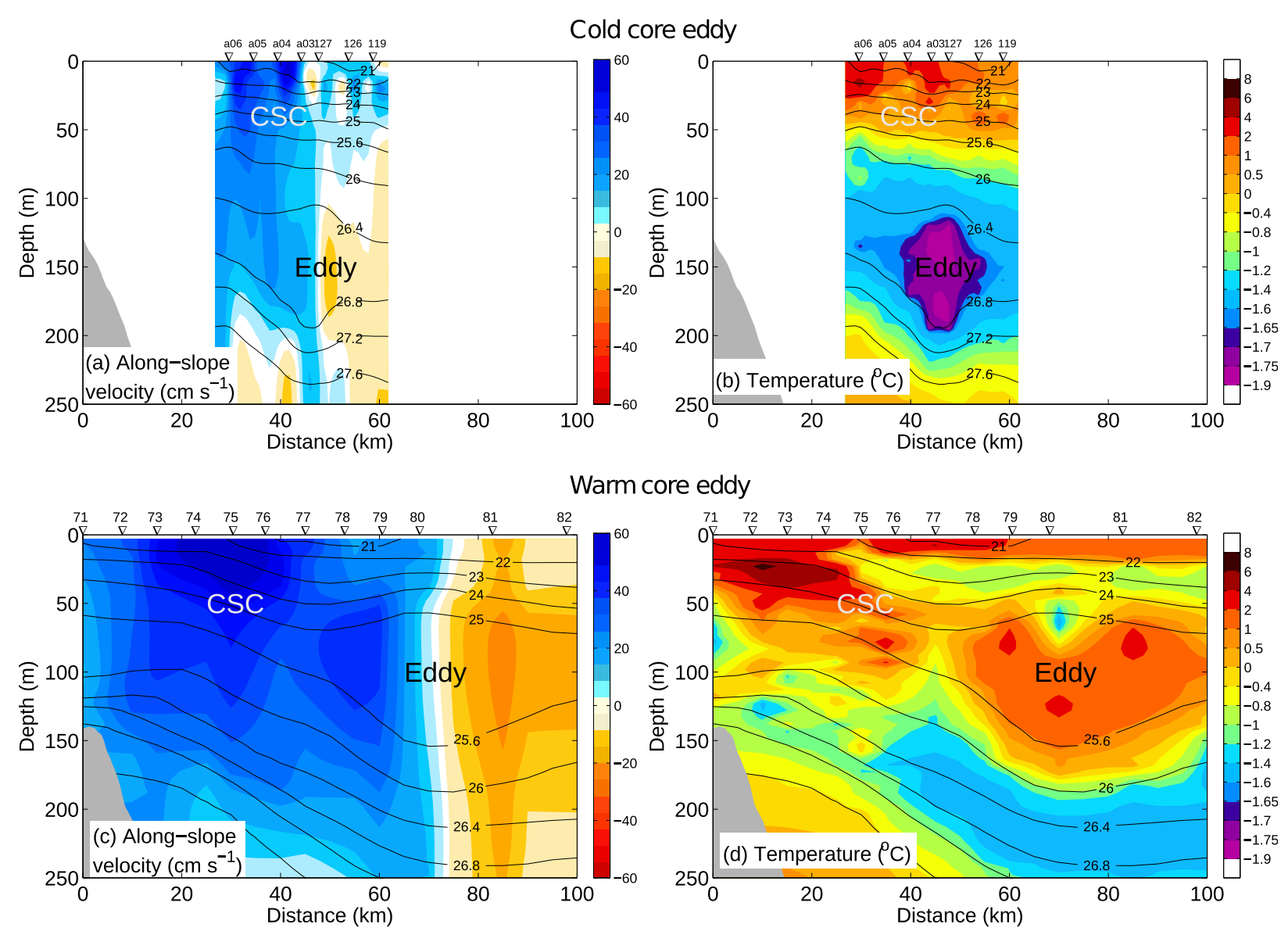

FIG. 8. (top) Vertical sections from an occupation near transect 8 in September 2004 showing a cold core eddy (Scott et al. 2019) and (bottom) near transect 5 in August 2017 showing a warm core eddy. (a),(c) Absolute geostrophic velocity (color) overlain by potential density (contours; $\mathrm{kg} \mathrm{m}^{-3}$ ). Positive velocity is northwestward (away from Barrow Canyon). The labels denote the Chukchi Slope Current (CSC) and the anticyclonic eddy. CTD station locations are marked along the top. (b),(d) Potential temperature (color) overlain by potential density (contours).

occurrences of warm water were less continuous as we can identify some smoothly varying features and some strongly intermittent patches within the current (especially for float $\mathrm{C}$ ). We note that the decrease in velocity, along with the change in temperature of the current from warm to cold, could also be explainable by a temporal or spatial change in the CSC rather than a consequence of the eddy encounter. Since the floats spent roughly 4-5 days seaward of the main flow of the CSC, it could be that during this intervening period the current slowed and cooled due to other reasons. For example, the wind stress curl on the Chukchi shelf transitioned from positive to negative as the floats were rejoining the current, which would tend to weaken the CSC.

On 24 September the two leading floats $\mathrm{C}$ and $\mathrm{E}$ took different paths: $\mathrm{C}$ started to progress into the Northwind Abyssal Plain to the east before going back to the west; E progressed northward more in line with the bathymetry toward the Chuckhi Plateau. Later on, floats A and B did a short excursion into the Northwind Abyssal Plain as well. Overall, these float trajectories suggest that at least part of the water in the CSC is able to get entrained into the edge of the Beaufort Gyre in this general vicinity. We identified the corresponding location [line (v)] in Fig. 5 as the end of a coherent and localized CSC current, around $75^{\circ} 30^{\prime} \mathrm{N}$, which can be seen as transition to a more widespread outflow toward the Northwind Abyssal Plain and the Chukchi Plateau. Around 10 October we lost track of the floats likely because of ice coverage in this region. Interestingly, warm water was still measured in the last few profiles.

\section{Summary and discussion}

We have presented results from a field study investigating the evolution and fate of the Chukchi Slope 
Current (CSC). A novel method was employed using profiling ALTO floats as quasi-Lagrangian particles deployed across the current. In addition to this, velocity data were collected along a set of transects using the shipboard ADCP. The transect data showed good agreement with earlier measurements of the CSC during this time of year, revealing a strong surface intensified current flowing westward along the continental slope. The corresponding volume flux estimates ranged from near zero to nearly $2 \mathrm{~Sv}$. This wide range can be explained by the variation in wind forcing during the cruise: the first part of the survey was characterized by positive wind stress curl on the Chukchi shelf, which is conducive for a strong CSC, while the latter part of the survey was characterized by negative wind stress curl on the shelf, which weakens or reverses the CSC.

The float trajectories were characterized into three basic regimes. Initially the floats traveled rapidly in the CSC, turning sharply to the north as they negotiated Hanna Canyon. This path is consistent with the shipboard ADCP transect data. The next phase occurred sometime after the floats had passed the Northwind Ridge, when they abruptly slowed, peeled off sequentially, and four of them veered offshore (only the shoreward-most float continued to follow an isobath). We argue that this interruption was likely caused by the CSC interacting with a cold-core, anticyclonic eddy at the offshore edge of the current. While not identified in our dataset, such eddies are common in this region, and are known to come in contact with the CSC. This presumed encounter with the eddy permanently expelled the offshore-most float from the CSC, but the three other floats eventually rejoined the CSC and proceeded northward again. During the final phase, the floats started to diverge and take more chaotic trajectories, entering the western side of the Northwind Abyssal Plain. It is likely that the floats were becoming entrained into the edge of the Beaufort Gyre at this point.

The water mass structure measured by the floats also varied along their pathways. During the initial phase, the CSC was advecting a range of Pacific summer and winter waters, including the very warm and relatively fresh Alaskan Coastal Water (ACW) in the depth range 20-40 m. This supports the notion that the CSC originates from the outflow from Barrow Canyon, which has been argued in previous studies. During the eddy encounter the ACW signature disappeared. This provides supporting evidence that the floats were pulled out of the core of the CSC by the anticyclone. After the three floats rejoined the CSC, the ACW signature did not reappear. Instead, the water mass occupying this depth range was predominantly Bering Summer Water (BSW). It is not clear if the floats simply measured a different part of the CSC upon rejoining the current, or if lateral mixing during the eddy encounter converted the ACW to BSW. In any case, the CSC continued to advect warm water to the north until the current eventually subducted under the ice.

Our results have provided new observational insights regarding the fate of the CSC. The previous study of Corlett and Pickart (2017) showed that the current typically resides on the upper continental slope (median isobath of $238 \mathrm{~m}$ ), consistent with the surface drifter results of Stabeno et al. (2018). Notably, the orientation of the isobaths on the upper Chukchi slope (shallower than about $300 \mathrm{~m}$ ) are oriented more zonally to the west of the Northwind Ridge than those of the deep slope (deeper than about $400 \mathrm{~m}$ ). This suggests that when the CSC is located over relatively shallow depths it might continue westward toward the East Siberian Sea, while in those cases when it is situated in deeper water it will flow more northward into the Chukchi Borderland. The results of Corlett and Pickart (2017) suggest that the former scenario might be more common, although the divergence of the isobaths could lead to a bifurcation of the current.

The float trajectories presented here suggest that there is another aspect of the topography that could play a critical role in the fate of the CSC: in particular, Hanna Canyon. Consistent with the numerical study of Hyun (2004), as the CSC encountered the dynamically wide canyon it flowed across isobaths to the far side of the canyon, before turning anticyclonically to the north. This abrupt turn was likely due to the current trying to conserve its potential vorticity when experiencing layer compression as it flowed up the far side of the canyon. A nearly identical northward excursion of the CSC on the western flank of Hanna Canyon was reported by Scott et al. (2019). While other factors such as wind (Li et al. 2019) and instabilities (Corlett and Pickart 2017) undoubtedly influence the path of the CSC, the evidence presented here in conjunction with the previous observations of Scott et al. (2019) implicate the topography of the canyon as a major factor. This is supported by the fact that when the ALTO floats turned offshore, the wind stress curl on the Chukchi shelf was in fact conducive to drive an onshore excursion of the CSC.

It is intriguing to think that a local bathymetric feature such as Hanna Canyon could help dictate the downstream path of the CSC, and in turn influence the fate of most of the Pacific-origin water entering the Arctic Ocean. If the CSC were to remain on the upper Chukchi slope it would flow toward the Eurasian Arctic. By contrast, if it gets diverted to the north-the fate suggested by the float data presented here-it would be more apt to get entrained in the Beaufort Gyre, 
trapping the water in the Amerasian Arctic. Further work will be necessary to better determine the likelihood of these different scenarios, as well as the role of CSC-eddy interaction in altering the current and the water masses it advects.

Acknowledgments. This work was principally supported by the Stratified Ocean Dynamics of the Arctic (SODA) program under ONR Grant N000141612450. S.B. wants to thank Labex iMust for supporting his research. R.S.P. acknowledges U.S. National Science Foundation Grants OPP-1702371, OPP-1733564, and PLR-1303617. P.L. acknowledges National Oceanic and Atmospheric Administration Grant NA14-OAR4320158. M.L. acknowledges National Natural Science Foundation of China Grants 41706025 and 41506018 . T.P. thanks ENS de Lyon for travel support funding. The authors gratefully acknowledge the support of Steve Jayne, Pelle Robins, and Alex Ekholm at the Woods Hole Oceanographic Institution for preparation, deployment, and data provision for the ALTO floats. Chanhyung Jeon assisted in preparing and deploying the floats. The invaluable support of the crew of the R/V Sikuliaq is also gratefully acknowledged.

\section{REFERENCES}

Berrisford, P., D. Dee, K. Fielding, M. Fuentes, P. Kallberg, S. Kobayashi, and S. Uppala, 2009: The ERA-Interim archive: Version 1.0. ERA Rep. Series 1, 16 pp., http://ecmwf.int/ publications/library/do/references/show?id $=89203$.

Coachman, L. K., K. Aagaard, and R. B. Tripp, 1975: Bering Strait: The Regional Physical Oceanography. University of Washington Press, $172 \mathrm{pp}$.

Corlett, B. W., and R. S. Pickart, 2017: The Chukchi Slope Current. Prog. Oceanogr., 153, 50-65, https://doi.org/10.1016/ j.pocean.2017.04.005.

Dee, D. P., and Coauthors, 2011: The ERA-Interim reanalysis: Configuration and performance of the data assimilation system. Quart. J. Roy. Meteor. Soc., 137, 553-597, https://doi.org/ 10.1002/qj.828.

Fine, E., J. MacKinnon, M. Alford, and J. Mickett, 2018: Microstructure observations of turbulent heat fluxes in a warm-core Canada basin eddy. J. Phys. Oceanogr., 48, 2397-2418, https://doi.org/10.1175/JPO-D-18-0028.1.

Gong, D., and R. Pickart, 2015: Summertime circulation in the eastern Chukchi Sea. Deep-Sea Res. II, 118, 18-31, https:// doi.org/10.1016/j.dsr2.2015.02.006.

Hickey, B., 1997: The response of a steep-sided, narrow canyon to time-variable wind forcing. J. Phys. Oceanogr., 27, 697-726, https://doi.org/10.1175/1520-0485(1997)027<0697: TROASS $>2.0 . \mathrm{CO} ; 2$.

Hyun, K.-H., 2004: The effect of submarine canyon width and stratification on coastal circulation and across shelf exchange. Ph.D. thesis, Old Dominion University, 125 pp.

Klinck, J., 1996: Circulation near submarine canyons: A modeling study. J. Geophys. Res., 101, 1211-1223, https://doi.org/ 10.1029/95JC02901.
Li, M., R. Pickart, M. Spall, T. Weingatner, P. Lin, G. Moore, and Y. Qi, 2019: Circulation of the Chukchi Sea shelfbreak and slope from moored timeseries. Prog. Oceanogr., 172, 14-33, https://doi.org/10.1016/j.pocean.2019.01.002.

Lin, P., R. Pickart, L. McRaven, K. Arrigo, F. Bahr, K. Lowry, D. Stockwell, and C. Mordy, 2019: Water mass evolution and circulation of the northeastern Chukchi Sea in summer: Implications for nutrient distributions. J. Geophys. Res. Oceans, 124, 4416-4432, https://doi.org/10.1029/2019JC015185.

Lowry, K., R. Pickart, M. Mills, Z. Brown, G. van Dijken, N. Bates, and K. Arrigo, 2015: The influence of winter water on phytoplankton blooms in the Chukchi Sea. DeepSea Res. II, 118, 53-72, https://doi.org/10.1016/j.dsr2. 2015.06.006.

Manley, T., and K. Hunkins, 1985: Mesoscale eddies of the Arctic Ocean. J. Geophys. Res., 90, 4911-4930, https://doi.org/ 10.1029/JC090iC03p04911.

Mathis, J., R. Pickart, D. Hansell, D. Kadko, and N. Bates, 2007: Eddy transport of organic carbon and nutrients from the Chukchi shelf into the deep Arctic basin. J. Geophys. Res., 112, C05011, https://doi.org/10.1029/2006JC003899.

Nikolopoulos, A., R. S. Pickart, P. S. Fratantoni, K. Shimada, D. J. Torres, and E. P. Jones, 2009: The western Arctic boundary current at $152^{\circ} \mathrm{W}$ : Structure, variability, and transport. Deep-Sea Res. II, 56, 1164-1181, https://doi.org/10.1016/ j.dsr2.2008.10.014.

Pacini, A., G. Moore, R. Pickart, C. Nobre, F. Bahr, K. Vage, and K. Arrigo, 2019: Characteristics and transformation of the Pacific winter water on the Chukchi Sea shelf in late-spring. J. Geophys. Res. Oceans, 124, 7153-7177, https://doi.org/ 10.1029/2019JC015261.

Paquette, R., and R. Bourke, 1974: Observations on the coastal current of Arctic Alaska. J. Mar. Res., 32, 195-207.

Pickart, R., 2004: Shelfbreak circulation in the Alaskan Beaufort sea: Mean structure and variability. J. Geophys. Res., 109, C04024, https://doi.org/10.1029/2003JC001912.

_ , and W. Smethie, 1998: Temporal evolution of the deep western boundary current where it enters the subtropical domain. Deep-Sea Res. I, 45, 1053-1083, https://doi.org/10.1016/ S0967-0637(97)00084-8.

, T. Weingartner, S. Zimmermann, D. Torres, and L. Pratt, 2005: Flow of winter-transformed Pacific water into the western Arctic. Deep-Sea Res. II, 52, 3175-3198, https:// doi.org/10.1016/j.dsr2.2005.10.009.

, G. Moore, C. Mao, F. Bahr, C. Nobre, and T. Weingartner, 2016: Circulation of winter water on the Chukchi shelf in early summer. Deep-Sea Res. II, 130, 56-75, https://doi.org/10.1016/ j.dsr2.2016.05.001.

Pinkel, R., M. Buijsman, and J. Klymak, 2012: Breaking topographic lee waves in a tidal channel in Luzon Strait. Oceanography, 25, 160-165, https://doi.org/10.5670/oceanog.2012.51.

Plueddemann, A., R. Krishfield, T. Takizawa, K. Hatakeyama, and S. Honjo, 1998: Upper ocean velocities in the Beaufort Gyre. Geophys. Res. Lett., 25, 183-186, https://doi.org/ 10.1029/97GL53638.

Scott, R. M., R. S. Pickart, P. Lin, A. Munchow, M. Li, D. A. Stockwell, and J. A. Brearley, 2019: Three-dimensional structure of a cold-core Arctic eddy interacting with the Chukchi Slope Current. J. Geophys. Res. Oceans, 124, 83758391, https://doi.org/10.1029/2019JC015523.

Spall, M. A., R. S. Pickart, M. Li, M. Itoh, P. Lin, T. Kikuchi, and Y. Qi, 2018: Transport of Pacific water into the Canada Basin and the formation of the Chukchi Slope Current. 
J. Geophys. Res. Oceans, 123, 7453-7471, https://doi.org/ 10.1029/2018JC013825.

Stabeno, P., N. Kachel, C. Ladd, and R. Woodgate, 2018: Flow patterns in the eastern Chukchi Sea: 2010-2015. J. Geophys. Res. Oceans, 123, 1177-1195, https://doi.org/10.1002/2017JC013135.

Timmermans, M.-L., J. Marchall, A. Proshutinsky, and J. Scott, 2017: Seasonally derived components of the Canada Basin halocline. Geophys. Res. Lett., 44, 5008-5015, https://doi.org/ 10.1002/2017GL073042.

Watanabe, E., J. Onodera, M. Itoh, S. Nishino, and T. Kikuchi, 2017: Winter transport of subsurface warm water toward the Arctic Chukchi borderland. Deep-Sea Res. I, 128, 115-130, https://doi.org/10.1016/j.dsr.2017.08.009.

Weingartner, T., K. Aagaard, R. Woodgate, S. Danielson, Y. Sasaki, and D. Cavalieri, 2005: Circulation on the north central Chukchi
Sea shelf. Deep-Sea Res. II, 52, 3150-3174, https://doi.org/ 10.1016/j.dsr2.2005.10.015.

Williams, W., E. Carmack, K. Shimada, H. Melling, K. Aagaard, R. Macdonald, and R. Grant Ingram, 2006: Joint effects of wind and ice motion in forcing upwelling in Mackenzie Trough, Beaufort Sea. Cont. Shelf Res., 26, 2352-2366, https:// doi.org/10.1016/j.csr.2006.06.012.

Zhao, M., M. L. Timmermans, S. Cole, R. Krishfield, A. Proshutinsky, and J. Toole, 2014: Characterizing the eddy field in the Arctic Ocean halocline. J. Geophys. Res. Oceans, 119, 8800-8817, https:// doi.org/10.1002/2014JC010488.

— M.-L. Timmermans, S. Cole, R. Krishfield, and J. Toole, 2016: Evolution of the eddy field in the Arctic Ocean's Canada Basin, 2005-2015. Geophys. Res. Lett., 43, 8106-8114, https:// doi.org/10.1002/2016GL069671. 